\title{
Tingkat Efikasi Diri Siswa Ditinjau dari Program Studi Keahlian dan Jenis Kelamin pada Siswa SMK Muhammadiyah 1 Sleman Yogyakarta
}

\author{
Kamaruddin \\ STKIP Singkawang, Singkawang, Indonesia \\ Kamaruddinoke@yahoo.com
}

Keywords::

Efikasi diri siswa, program studi keahlian, jenis

kelamin.

\begin{abstract}
Tingkat Efikasi Diri Siswa Ditinjau Dari Program Studi Keahlian dan Jenis Kelamin Pada Siswa SMK Muhammadiyah 1 Sleman Yogyakarta. Penelitian ini bertujuan untuk mengetahui tingkat efikasi diri siswa secara keseluruhan. Aspek efikasi diri serta ditinjau dari program studi keahlian dan jenis kelamin pada siswa SMK Muhammadiyah 1 Sleman Yogyakarta. Penelitian ini menggunakan pendekatan kuantitatif, dengan jenis penelitian adalah studi deskriptif. Subjek dalam penelitian ini adalah 140 siswa kelas XI SMK Muhammadiyah 1 Sleman Yogyakarta. Pengambilan subjek menggunakan teknik purposive sampling. Pengumpulan data menggunakan skala efikasi diri. Hasil penelitian menunjukkan bahwa tingkat efikasi diri siswa program studi keahlian Teknik Kendaraan Ringan (TKR) lebih tinggi dari program studi keahlian Multimedia. Tingkat efikasi diri siswa ditinjau dari jenis kelamin laki-laki lebih tinggi dari siswa perempuan.
\end{abstract}

\section{PENDAHULUAN}

Belajar merupakan salah satu faktor yang sangat penting dalam menentukan keberhasilan siswa dalam hidupnya. Proses belajar siswa diakibatkan oleh dua aspek, yaitu aspek yang berasal dari dalam diri siswa (aspek internal) dan aspek yang berasal dari luar diri siswa (aspek eksternal). Salah satu aspek eksternal yang berfungsi sangat besar dalam menentukan keberhasilan siswa adalah sekolah. Sekolah merupakan agen informasi yang diperlukan siswa untuk menambah pengetahuan dan keahlian melalui berbagai kegiatan yang dilaksanakan baik di bidang akademik maupun non akademik. Selama mengikuti proses pembelajaran, terdapat bermacam-macam masalah yang sering dihadapi siswa, seperti rendahnya prestasi yang dicapai, kurangnya keaktifan siswa dalam mengikuti proses pembelajaran, dan rendahnya minat dan motivasi siswa untuk mengikuti kegiatan pembelajaran.

Salah satu hal yang menjadi penyebab terjadinya masalah tersebut adalah rendahnya efikasi diri yang dimiliki siswa dalam mengikuti proses pembelajaran. Efikasi diri membentuk kesungguhan siswa dengan penguasaan untuk melakukan suatu tugas khusus. Efikasi diri sangat mempengaruhi motivasi seseorang dalam menumbuhkan potensinya, mengejar prestasi yang diraih dan juga mempengaruhi keyakinan diri dalam bersosialisasi di lingkungannya. Menurut Bandura (2007, p.298) bahwa efikasi diri ikut mempengaruhi siswa dalam menetukan suatu tugas, usaha, keseriusan, dan kinerja individu. Sependapat dengan hal tersebut Baleghizadeh et al (2013, p.43) menyatakan self-efficacy to 
individuals'beliefs in their capacity to accomplish specific tasks, assumed to have a strong influence on levels of persistence and the choices individuals makes. Efikasi diri merupakan keyakinan siswa untuk mengatasi tugas-tugas tertentu yang diasumsikan memiliki pengaruh kuat pada tingkat ketekunan dan pilihan yang dilakukan.

Pentingnya efikasi diri bagi siswa merupakan penentu kinerja yang signifikan yang beroperasi secara parsial dan indenpenden dari keterampilan dasar. Roffi et al (2012, p.61) menyatakan self-efficacy, as a key element of social cognitive theory, refers to beliefs in one's capabilities to organize and execute the courses of action required to produce given attainments.

Efikasi diri sebagai elemen kunci teori kognitif sosial, mengarahkan pada keyakinan pada kemampuan siswa untuk mengatur dan melakukan tindakan diperlukan untuk menghasilkan pencapaian yang dibutuhkan. Dengan kata lain, efikasi diri berlaku sebagai mesin penyemangat kenirja. Oleh karena itu, tidaklah mengherankan jika siswa memiliki efikasi diri yang kuat, maka bermotivasi tinggi dan bahkan membuktikan tinjauan yang ekstrim dalam menghadapi suatu situasi tersebut. Sebaliknya siswa yang meragukan kemampuannya untuk berprestasi mungkin akan gagal dalam melakukan kegiatan yang berharga. Menyerah ketika yang dilakukan menjadi berat, cenderung panik selama melakukan tugas, dan sering kali "nihil" dan gagal untuk berpikir dan bertindak dengan analisis yang tenang (Pervin et al, 2004, p.443).

Berdasarkan wawancara dengan guru bimbingan dan konseling dan hasil penyebaran skala efikasi diri di SMK Muhammadiyah 1 Sleman Yogyakarta ditemukan sebagian siswa memiliki efikasi diri rendah. Hal ini dapat dilihat dari perilaku siswa dalam kesehariannya yang masih meragukan kemampuannya dalam proses belajar, misalnya mencontek saat mengerjakan tugas dan ujian semester, meragukan jawabannya dan lebih meyakini jawaban teman (kadang-kadang mengganti jawaban yang sudah ditulis dengan jawaban baru dari teman), enggan mengajukan pendapat atau menjawab pertanyaan guru, mengeluh dalam mengerjakan banyak tugas, dan bahkan sering tidak mengerjakan tugas dan tanggung jawab yang dibebankan kepada dirinya.

Hasil yang diperoleh dari sebaran skala efikasi diri yang diberikan kepada 30 siswa kelas XI yang dipilih oleh guru bimbingan dan konseling di SMK Muhammadiyah 1 Sleman Yogyakarta sebagai berikut: aspek kemampuan untuk menyelesaikan tugas dengan kesulitan berbeda sebanyak 12 siswa dari 30 siswa dengan persentase 40\%; aspek kemampuan menilai keyakinan diri dalam menyelesaikan tugas sebanyak 8 siswa dari 30 siswa dengan persentase 27\%; aspek keyakinan dan kemampuan dalam usaha yang akan dicapai meskipun terdapat kesulitan dan rintangan sebanyak 10 siswa dari 30 siswa dengan persentase 33\%. Dari hasil skala tersebut dapat disimpulkan bahwa sebagian siswa di SMK Muhammadiyah 1 Sleman Yogyakarta memiliki permasalahan terkait efikasi diri.

Permasalahan efikasi diri yang dimiliki oleh sebagian siswa SMK Muhammadiyah 1 Sleman Yogyakarta disebabkan oleh beberapa hal misalnya: rendahnya keyakinan siswa dalam menyelesaikan tugas yang diberikan oleh guru mata pelajaran, kurangnya motivasi siswa dalam belajar pada pelajaran yang dianggap sulit, ketidakmampuan siswa dalam mengatur tindakan untuk mencapai tujuan belajar, rendahnya keyakinan belajar siswa dalam usaha yang akan dicapai, ketidakmampuan belajar siswa untuk bertindak pada situasi sulit dan hambatan.

Esen (2017, p.144) menyatakan self efficacy is the belief which people have the impact on the events that affect their lives in order to produce the required performance levels. Efikasi diri adalah keyakinan dimana individu memiliki dampak pada kejadian yang mempengaruhi kehidupannya sehingga dapat meningkatkan keterampilan yang diperlukan. Bandura (1997, p.3) mengatakan efikasi diri dipengaruhi oleh aspek penguasan pengalaman, pengalaman seseorang, keyakinan sosial dan tindakan (kecemasan, stres, kelelahan atau emosi yang memiliki efek pada keyakinan siswa). Berdasarkan permasalahan dan hasil penelitian tersebut, selanjutnya peneliti tertarik untuk melakukan 
penelitian tentang tingkat efikasi diri siswa ditinjau dari program studi keahlian dan jenis kelamin siswa SMK Muhammadiyah 1 Sleman Yogyakarta.

Terdapat dua rumusan masalah dalam penelitian ini yaitu: 1) Sejauh mana tingkat efikasi diri siswa ditinjau dari program studi keahlian pada siswa SMK Muhammadiyah 1 Sleman Yogyakarta? 2) Sejauh mana tingkat efikasi diri siswa ditinjau dari jenis kelamin pada siswa SMK Muhammadiyah 1 Sleman Yogyakarta?

\section{METODE}

Penelitian yang digunakan dalam penelitian ini adalah pendekatan kuantitatif. Jenis penelitian yang digunakan adalah studi deskriptif yaitu dengan menganalisis tingkat efikasi diri siswa secara keseluruhan, efikasi diri per aspek, program studi keahlian dan jenis kelamin pada siswa SMK Muhammadiyah 1 Sleman Yogyakarta.

Subjek pada penelitian ini adalah siswa kelas XI dengan Program studi keahlian (Teknik kendaraan ringan dan Multimedia) dan siswa jenis kelamin Laki-laki dan jenis kelamin perempuan) di SMK Muhammadiyah 1 Sleman Yogyakarta berjumlah 140 siswa yang kemudian diberikan sebaran skala efikasi diri. Penentuan sampel penelitian menggunakan teknik purposive sampling.

Tingkat efikasi diri siswa diukur menggunakan skala efikasi diri. Skala efikasi diri divalidasi oleh ahli kemudian diujicobakan kepada 30 siswa SMK. Selanjutnya tingkat efikasi diri siswa dianalisis menggunakan SPSS 20 for windows.

\section{HASIL DAN PEMBAHASAN}

Hasil penelitian yang dilakukan di SMK Muhammadiyah 1 Sleman Yogyakarta menunjukkan bahwa tingkat efikasi diri siswa diperoleh skor rerata (mean) sebesar 111,94; simpangan baku (standar deviation) sebesar 24,88; nilai tengah (median) sebesar 111,00; dan modus (mode) sebesar 115,00 atau dengan persentase 15 siswa terkategori sangat tinggi sebesar $11 \%, 50$ siswa terkategori tinggi sebesar $36 \%, 62$ siswa terkategori rendah sebesar 44\% dan 13 siswa terkategori sangat rendah sebesar 9\%.

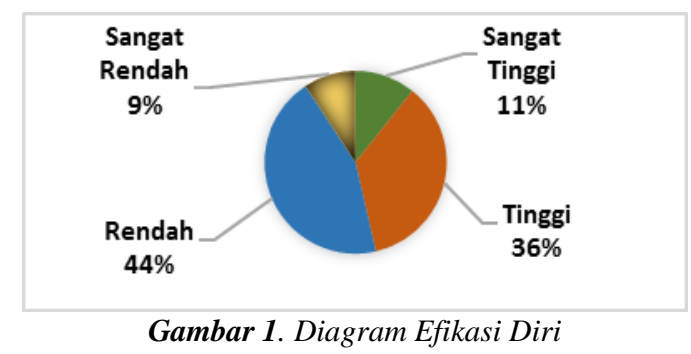

Selanjutnya efikasi diri siswa ditinjau dari per aspek level difficullty, generallty dan strength sangat rendah. Berdasarkan analisis data pada aspek level difficullty diperoleh skor rerata (mean) sebesar 40,65; simpangan baku (standar deviation) sebesar 9,28; nilai tengah (median) sebesar 39,00; dan modus (mode) sebesar 35,00 atau dengan persentase, 30 siswa terkategori sangat tinggi sebesar 22\%, 30 siswa terkategori tinggi sebesar 21\%, 66 siswa berkategori rendah sebesar 47\% dan 14 siswa terkategori sangat rendah sebesar $10 \%$. 


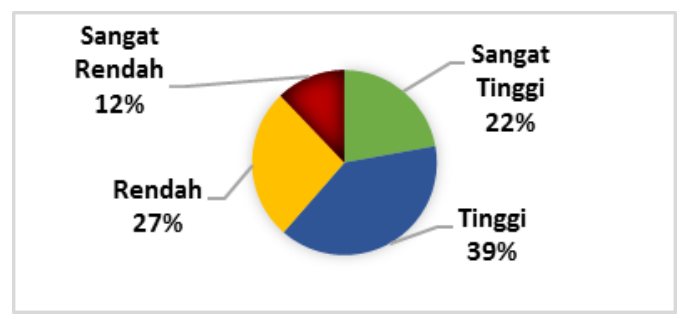

Gambar 2. Diagram Aspek Level Difficullty

Selanjutnya efikasi diri ditinjau dari aspek generallty, berdasarkan analisis data diperoleh skor rerata (mean) sebesar 41,63; simpangan baku (standar deviation) sebesar 10,16; nilai tengah (median) sebesar 44,50; dan modus (mode) sebesar 45,00 atau dengan persentase 31 siswa terkategori sangat tinggi sebesar 22\%, 55 siswa terkategori tinggi sebesar 39\%, 37 siswa terkategori rendah sebesar $27 \%$ dan 17 siswa terkategori sangat rendah sebesar $12 \%$.

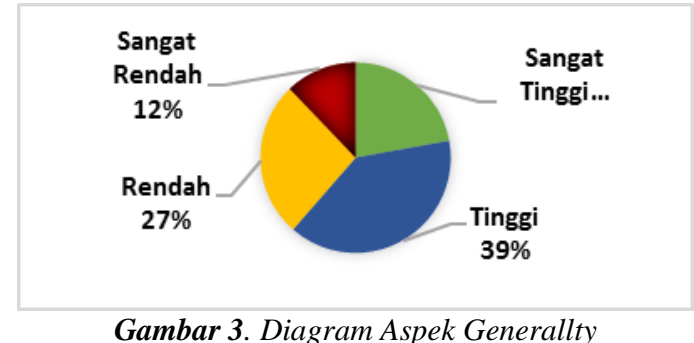

Selanjutnya efikasi diri ditinjau dari aspek strength, berdasarkan analisis data diperoleh skor rerata (mean) sebesar 29,01; simpangan baku (standar deviation) sebesar 7,44; nilai tengah (median) sebesar 29,00; dan modus (mode) sebesar 27,00 atau dengan persentase 19 siswa terkategori sangat tinggi sebesar 13\%, 53 siswa terkategori tinggi sebesar 38\%, 53 siswa terkategori rendah sebesar 38\% dan 15 siswa terkategori sangat rendah sebesar $11 \%$.

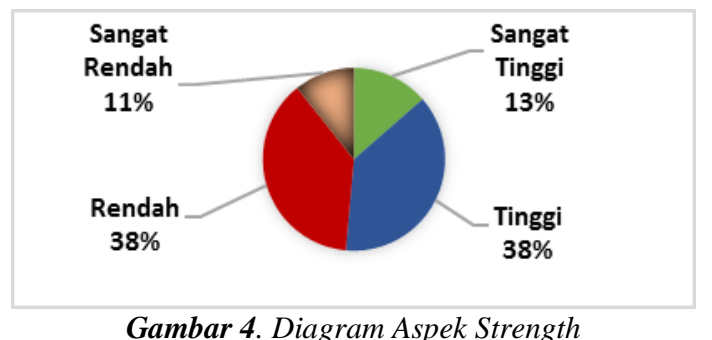

Selanjutnya efikasi diri ditinjau dari program studi keahlian Teknik kendaraan ringan (TKR) dan Multimedia. Berdasarkan tingkat efikasi diri ditinjau dari program studi keahlian program teknik kendaran ringan (TKR) diperoleh skor rerata (mean) sebesar 110,32; simpangan baku (standar deviation) sebesar 23,59; nilai tengah (median) sebesar 109,50; dan modus (mode) sebesar 89,00 atau dengan persentase, 8 siswa terkategori sangat tinggi sebesar $9 \%, 30$ siswa terkategori tinggi sebesar $35 \%, 41$ siswa terkategori rendah sebesar $48 \%$ dan 7 siswa terkategori sangat rendah sebesar $48 \%$.

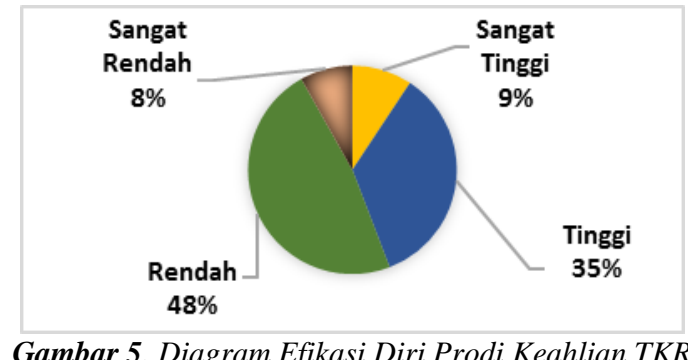


Selanjutnya efikasi diri pada program studi keahlian Multimedia diperoleh skor rerata (mean) sebesar 114,51; simpangan baku (standar deviation) sebesar 26,83; nilai tengah (median) sebesar 112,50; dan modus (mode) sebesar 115,00 atau dengan persentase 7 siswa terkategori sangat tinggi sebesar 13\%, 20 siswa terkategori tinggi sebesar 37\%, 20 siswa terkategori rendah sebesar 37\% dan 7 siswa terkategori sangat rendah sebesar $13 \%$.

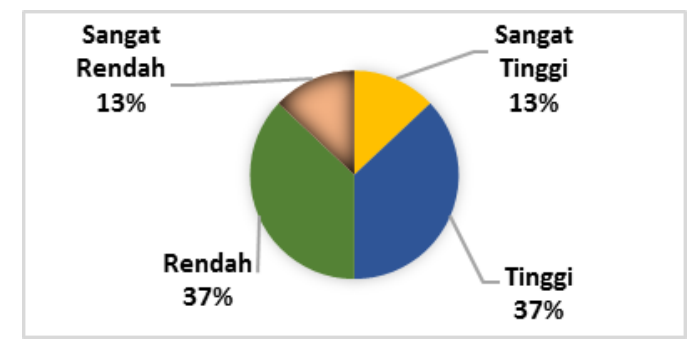

Gambar 6. Diagram Efikasi Diri Prodi Keahlian Multimedia

Selanjutnya efikasi diri siswa ditinjau dari jenis kelamin laki-laki dan perempuan. Tingkat efikasi diri siswa jenis kelamin laki-laki diperoleh skor rerata (mean) sebesar 111,24; simpangan baku (standar deviation) sebesar 24,84; nilai tengah (median) sebesar 111,00; dan modus (mode) sebesar 117,00 atau dengan persentase 12 siswa terkategori sangat tinggi sebesar $10 \%, 49$ siswa terkategori tinggi sebesar $38 \%, 54$ siswa terkategori rendah sebesar $42 \%$ dan 13 siswa terkategori sangat rendah sebesar $10 \%$.

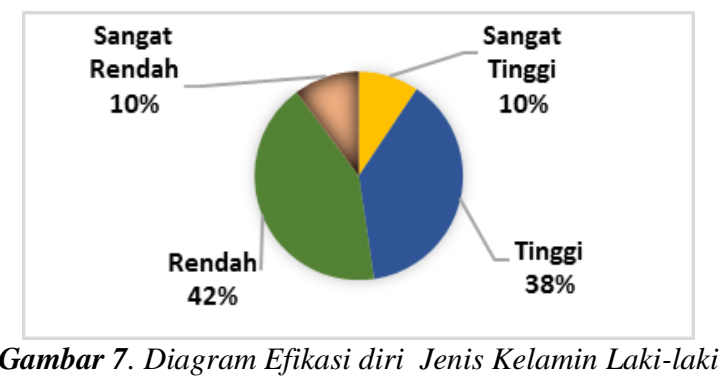

Selanjutnya efikasi diri ditinjau jenis kelamin perempuan diperoleh skor rerata (mean) sebesar 112,25; simpangan baku (standar deviation) sebesar 23,69; nilai tengah (median) sebesar 108,00; dan modus (mode) sebesar 148,00 atau dengan persentase 2 siswa terkategori sangat tinggi sebesar 17\%, 2 siswa terkategori tinggi sebesar 17\%, 7 siswa terkategori rendah sebesar 58\% dan 1 siswa terkategori sangat rendah sebesar $8 \%$.

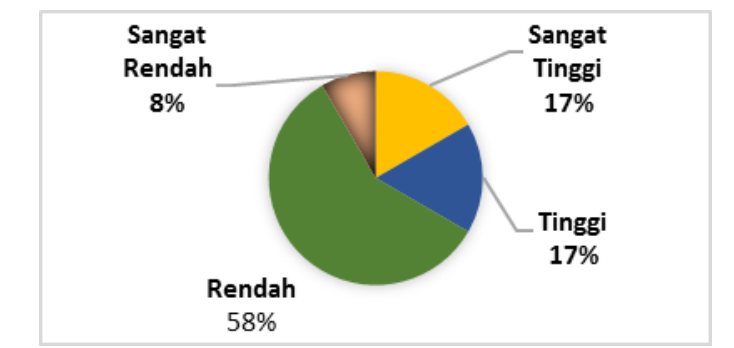

Gambar 8. Diagram Efikasi Diri Jenis Kelamin Perempuan

Berdasarkan hasil penelitian, menunjukkan bahwa tingkat efikasi diri siswa di SMK Muhammadiyah 1 Sleman Yogyakarta terkategori rendah. Efikasi diri siswa ditinjau dari aspek level difficullty terkategori rendah. Aspek generallty terkategori tinggi dan pada aspek strength terkategori tinggi. 
Tingkat efikasi diri siswa ditinjau dari program studi keahlian dan jenis kelamin pada siswa SMK Muhammadiyah 1 Sleman Yogyakarta dapat disimpulkan bahwa tingkat efikasi diri siswa ditinjau dari program studi keahlian Teknik kendaraaan ringan (TKR) lebih tinggi dari program studi keahlian Multimedia, selanjutnya efikasi diri ditinjau dari jenis kelamin (Laki-laki dan Perempuan) dapat disimpulkan bahwa tingkat efikasi diri siswa jenis kelamin laki-laki lebih tinggi dari jenis kelamin perempuan. Hal ini senada dengan temuan dari Fallan, L dan Opstad (2016) menunjukkan bahwa tingkat efikasi diri siswa laki-laki lebih tinggi dari siswa perempuan. Selanjutnya temuan dari Ozgen, K dan Bindak, R (2011) menunjukkan bahwa ada perbedaan signifikan terhadap efikasi diri pelajaran matematis dalam hal jenis kelamin, jenis sekolah, kelas, tingkat pelajaran matematika, status pendidikan orang tua.

Efikasi diri merupakan pengarahan diri pada keyakinan sejauh mana individu memperkirakan kemampuan dirinya dalam melaksanakan tugas atau melakukan suatu tugas yang dibutuhkan untuk mencapai suatu hasil tertentu. Keyakinan akan seluruh kemampuan meliputi kepercayaan diri, kemampuan menyesuaikan diri, kapasitas kognitif, kecerdasan dan kapasitas bertindak pada keadaan yang penuh tekanan.

Palmer (2015, p.27) self-efficacy has been defined as a person's judgments about his/her ability to organize and execute courses of action required to deal with prospective situations that contain many ambiguous, unpredictable, and often stressful, elements. Efikasi diri merupakan penilaian individu tentang kemampuannya mengatur dan melaksanakan tindakan yang diperlukan untuk menghadapi situasi yang prospektif bagian yang ambigu, tidak dapat diprediksi, dan sering menimbulkan stress.

Hoyle (2010, p.317) menyatakan lima sumber efikasi diri yaitu:

1) Performance Experiences

Keyakinan efikasi diri yang paling sangat dipengaruhi oleh diri sendiri.

2) Vicarious Experience

Pengamatan dari perilaku orang lain dan konsekuensi dari bagian pengalaman perilaku juga dapat mempengaruhi keyakinan efikasi diri karena menggunakan pengamatan dari orang lain untuk membentuk harapan tentang perilaku diri sendiri dan konsekuensinya.

3) Imaginal Experience

Membayangkan diri sendiri berperilaku secara efektif atau tidak efektif dalam situasi hipotetis juga dapat mempengaruhi keyakinan efiasi diri (misalnya, seperti ketika proses konseling intervensi yang sangat bergantung pada citra, seperti desensitisasi sistematis dan pemodelan.

4) Verbal Persuasion

Kekuatan persuasi verbal untuk mempengaruhi keyakinan efikasi diri tergantung pada faktor-faktor sumber seperti keahlian, kepercayaan, dan daya tarik, sebagai dekade penelitian tentang persuasi verbal dan perubahan sikap telah ditunjukkan.

5) Affective and Physiological States

Mempengaruhi efikasi diri ketika proses yang buruk atau kegagalan dirasakan dengan fisiologis menyenangkan dan kesuksesan dengan emosi yang menyenangkan.

Tingkat efikasi diri yang dimiliki individu dapat dilihat dari aspek efikasi diri. Efikasi diri yang dimiliki individu berbeda-beda, dapat dilihat berdasarkan aspek yang mempunyai implikasi penting pada perilaku. Zimmerman (2000, p. 83) tiga aspek dalam efikasi diri seseorang yang meliputi:

1) Level difficulty

Mengacu ketergantungan pada kesulitan tugas tertentu seperti mengeja kata-kata dan kesulitan menghitung tambahan.

2) Generality

Berkaitan dengan pengalihan keyakinan efikasi diri pada seluruh kegiatan, seperti aljabar statistik.

3) Strength

Merasakan kekuatan pada keyakinan individu atas kemampuannya menghadapi kesulitan dan rintangan. 
Beberapa aspek yang dapat mempengaruhi efikasi diri yang diperspektifkan oleh individu yang membentuk salah satu aspek penentu keberhasilan dalam performasi dan kemudian dapat pula menjadi aspek yang ditentukan oleh contoh kesuksesan atau kegagalan performasi yang pernah dialami. Feist and Gregory (2009, p.490) menyatakan faktor yang mempengaruhi efikasi diri yaitu:

1) Mastery Experiences

Peningkatan kinerja harapan melalui penguasan pengalaman efektif menurunkan kegagalan.

2) Social Modeling

Peningkatan harapan efikasi untuk menduplikat prestasi orang lain.

3) Social Persuasion

Persuasi sosial dapat ditingkatkan dan menurun melalui aktifitas yang di dorong oleh perilaku individu.

\section{KESIMPULAN DAN SARAN}

\section{Kesimpulan}

Berdasarkan hasil analisis dan pembahasan dapat disimpulkan bahwa tingkat efikasi diri siswa di SMK Muhammadiyah 1 Sleman Yogyakarta secara keseluruhan terkategori rendah. Efikasi diri siswa ditinjau dari per aspek (level difficullty, generallty dan strength) aspek level difficullty lebih rendah dari kedua aspek tersebut. Sedangkan efikasi diri ditinjau dari program studi keahlian, program studi keahlian teknik kendaraan ringan (TKR) lebih tinggi dari program studi keahlian Multimedia dan efikasi diri siswa jenis kelamin laki-laki lebih tinggi dari siswa perempuan.

Saran

Penelitian ini menyarankan kepada pihak Sekolah diharapkan kedepannya dapat menyiapkan prasarana yang memadai untuk kegiatan konseling individu dan konseling kelompok, bagi guru bimbingan dan konseling dapat memberikan layanan konseling kepada siswa yang memiliki efikasi diri yang rendah, dan bagi peneliti selanjutnya diharapkan dapat digunakan sebagai referensi pada penelitian selanjutnya yang berhubungan dengan efikasi diri siswa.

\section{DAFTAR PUSTAKA}

Bandura. A. (1997). Self-Efficacy: The Exercise of Control. New York: W. H. Freeman and Company. Baleghizadeh, S. et al. (2013). The Effect of Self-Assessment on EFL Learners' Self-Efficacy. Journal Revle Tesldu Canada. Vol 31. No 1.

Barrows, J. et al. (2013) Anxiety, Self-Efficacy, and College Exam Grades. Journal of Educational Research. Vol 1. No 3. Pp 204-208.

Esen, K. B. et al. (2017). High School Student's Cognitive Flexibilty is Predicted by Self-Efficacy and Achievement. Journal European of Education Studies. Vol 3. No 2. Pp 143-151.

Fallan, L. and Opstad, L. (2016). Student Self-Efficacy and Gender-Personality Interactions. Journal of Higher Education. Vol 5. No 3. Pp 32-44.

Feist. J. and Gregory, J. F. (2009). Theories Personality. USA: The McGraw-Hill Companies Inc.

Hoyle, R. H. (2010). Handbook of Personality and Self-Regulation. United Kingdom: Blackwell Publishing Ltd.

Odanga, S. J. et al. (2015). Influence of Gender on Teachers' Self-Efficacy in Secondary Schools of Kisumu County, Kenya. Journal of International Studies. Vol 4. No 3. Pp 189-198.

Ozgen, K and Bindak, R. (2011). Detemination of Self Efficacy Beliefs of High School Students Toward Math Literacy. Journal Educational Science. Vol 11. No 2. Pp 1085-1089.

Palmer, D. et al. (2015). Changes in Science Teaching Self-efficacy among Primary Teacher Education Students. Journal Australian of Theacher Education. Vol 4. No 12. Pp 27-40.

Pervin, L. A, et al. (2004). Personality: Theory and Research, 9th edition. Terj: Anwar A. K. Jakarta: Prenada Media Group.

Roffi, S. et al. (2012). Self-Efficacy in Second in Learning Contex. Journal Science and Education English Language Teaching. Vol 5. No 11. Pp 60-67. 


\section{Journal of Educational Review and Research}

Vol. 1 No. 2, December 2018: $51-58$

e-ISSN: 2597-9760, p-ISSN: 2597-9752

Stewart, G. et al. (2015). Anxienty and Self-Efficacy's Relationship with Undergraduate Student's Persceptions of the Use of Metacognitive Writeng Strategies. Journal the Schoorship of Teaching and Learning. Vol 6. No 1. Pp 1-17.

Zimmerman, B. J. (2000). Self-Efficacy: an Essential Motive to Learn. Contemporary Educational Psychology. New York: Academic Press. 